\section{RMD Open}

Rheumatic \&

Musculoskeletal Diseases

\title{
Association of the different types of radiographic damage with physical function in patients with rheumatoid arthritis: analysis of the RAPID trials
}

\author{
Ana Maria Gherghe, ${ }^{1,2}$ Sofia Ramiro, ${ }^{1}$ Robert Landewé, ${ }^{3,4}$ Carina Mihai, ${ }^{2}$ \\ Désirée van der Heijde ${ }^{1}$
}

To cite: Gherghe AM, Ramiro S, Landewé R, et al. Association of the different types of radiographic damage with physical function in patients with rheumatoid arthritis: analysis of the RAPID trials. RMD Open 2016;2: 000219 .

doi:10.1136/rmdopen-2015000219

- Prepublication history and additional material is available. To view please visit the journal online (http://dx.doi.org/10.1136/ rmdopen-2015-000219).

Received 4 December 2015 Revised 2 February 2016 Accepted 11 February 2016

CrossMark

For numbered affiliations see end of article.

Correspondence to Dr Ana Maria Gherghe; ana.gherghe@gmail.com

\section{ABSTRACT}

Objectives: To evaluate the separate effects of erosions (E) (bone damage), joint space narrowing (JSN) (cartilage loss) and (sub)luxation (SLUX) (soft tissue damage) in four different joint groups on physical disability in rheumatoid arthritis (RA).

Methods: 3-year follow-up data from the Rheumatoid Arthritis Preventlon of structural Damage (RAPID) 1 and 2 trials were used. These randomised controlled trials compared certolizumab plus methotrexate (MTX) versus MTX in patients with RA. Physical function was measured by Health Assessment Questionnaire (HAQ). Radiographic damage was measured by the van der Heijde-modified Sharp score; separate scores for E, JSN and SLUX were available. Generalised estimating equations were performed to assess the relationship between $H A Q$ and E, JSN and SLUX scores, separately and in all joint groups.

Results: In separate models for each type of damage and after adjusting for age, gender, baseline disease activity and treatment group, E and JSN were more strongly associated with $H A Q$ than with SLUX. In combined models, JSN was the only type of lesion associated with $\mathrm{HAQ}$ when all joints were included together. When separate joint groups were analysed, $E$ in the wrist and JSN in the metacarpophalangeal joints (MCPs) were most strongly associated with function.

Conclusions: Among RA-related joint damage, cartilage loss quantified by JSN is an important determinant of physical function. However, when analysing joint groups separately, erosive damage in the wrist and JSN in the MCPs had the most important influence on disability. These data indicate that the comprehensive assessment of joint damage is needed to reliably reflect disease-related damage.

\section{INTRODUCTION}

In patients with rheumatoid arthritis (RA), ongoing inflammatory activity and destruction of the joints may result in physical disability. ${ }^{1}$

\section{Key messages}

What is already known about this subject?

- In patients with rheumatoid arthritis, radiographic damage may impair physical function.

What does this study add?

- Erosions and joint space narrowing are both important elements of damage. The separate contribution of (sub)luxation to explaining physical function seems trivial.

How might this impact on clinical practice?

- In clinical practice, an aggregated score, such as Sharp-van der Heijde, is needed to reliably reflect disease-related damage.

While disability due to disease activity may be reversible, physical disability as a result of joint damage is considered widely irreversible. ${ }^{2}$ Several studies have looked at the relationship between radiographic damage and physical function in patients with $\mathrm{RA}^{3-5}$ concluding that any type of radiographic damage may impair physical function. ${ }^{6}$

Joint destruction includes damage of bone, cartilage and soft tissue, and these different structures can be evaluated separately on radiographs. In the van der Heijde modification of the Sharp score $(\mathrm{SvdH}),{ }^{7}$ bone damage, assessed on radiographs of hands and feet, is reflected by the erosion (E) score while cartilage and soft tissue damage is reflected by the joint space narrowing (JSN) score. Recent studies have suggested that JSN, rather than E, is associated with physical disability. ${ }^{1}$ However, the effect of 'true' JSN (as a surrogate for cartilage loss) and (sub) luxation (SLUX) (as a consequence of destruction of soft tissues, including ligaments) has been analysed separately in only 
one previous study. ${ }^{8}$ According to the $\mathrm{SvdH}$, every joint is assessed for JSN and the highest scores are assigned to joints with either severe JSN or SLUX, which may therefore reflect either severe cartilage loss or soft tissue damage, ${ }^{9}$ and it is conceivable that SLUX adds to irreversible physical disability.

Another outstanding question in this regard is whether the dominant effect of JSN on physical disability can be explained by preferential wrist involvement. A recent study of ours in a (different) longitudinal cohort of patients with RA did not show a clear relationship between E, JSN or SLUX as compared with Health Assessment Questionnaire (HAQ) score, but did show correlations with some aspects of functioning such as grip strength. An important limitation of that study was that radiographs of the feet were missing, while the small sample size may have precluded detecting subtle associations. ${ }^{8}$ To date, therefore, important aspects of explaining physical disability from radiographic damage are still lacking.

The aim of this study was to evaluate the separate effects of E (bone damage), JSN (cartilage loss) and SLUX (soft tissue damage) in four different joint groups on physical disability assessed by HAQ in patients with RA, using data from two prospective phase III randomised controlled trials (RCTs) on certolizumab pegol (CZP).

\section{METHODS}

\section{Study design}

The Rheumatoid Arthritis PreventIon of structural Damage (RAPID) 1 and 2 RCTs, have been conducted in adults with active RA who had inadequate prior response to methotrexate (MTX) therapy. The aim of these studies was to evaluate the efficacy and safety of two dosages of CZP and MTX in comparison with placebo (PBO) and MTX in patients with active RA. ${ }^{10} 11$ Briefly, in both trials, adult patients were eligible for inclusion if they had active RA with duration between 6 months and 15 years, and had received prior MTX for at least 6 months.

Patients were randomised 2:2:1 to one of two dosages of CZP (200 mg and $400 \mathrm{mg}$ ) plus MTX or PBO plus MTX. Patients who did not achieve an American College of Rheumatology (ACR) 20 response at weeks 12 and 14 were withdrawn from the studies and allowed to enter the open-label extensions (OLE) of the trials at week 16, with $400 \mathrm{mg}$ of CZP plus MTX (rescue medication). The double-blind $\mathrm{PBO}$ controlled part, RAPID 1, had a 52-week duration and included 982 patients; RAPID 2 had a 24-week duration and included 619 patients.

We received a $90 \%$ random sample of the subjects from the RAPID 1 and 2 trials with follow-up of up to 3 years, to perform the current analyses.

\section{Outcome}

Physical function was assessed using the $\mathrm{HAQ}^{12}$ at each visit. The HAQ includes 20 questions organised into 8 categories. Each question is scored on a scale ranging from 0 to 3 (from: 'without any difficulty' (score 0) to 'cannot be done at all' (score 3)). Aids or devices, if any, were also taken into consideration when scoring. The total HAQ-score, which ranges from 0 (no disability) to 3 (severe disability), is the grand mean of the highest scores per category.

\section{Radiographic assessments}

In RAPID 1, radiographs of hands and feet were performed at baseline, weeks 24 and 52 in the double-blind phase, and weeks 76, 100 and 148 in the OLE for 52-week completers. For patients who received rescue medication, radiographs were performed at baseline, week 16 and week 40 in the double-blind phase, then at weeks 64 and 112 in the OLE. In RAPID 2, radiographs of hands and feet were obtained at baseline and at week 24 in the double-blind phase, and weeks 48, 100 and 128 in OLE for 24-week completers. For patients who were rescued at week 16 , radiographs were performed at baseline and week 16 in the double-blind phase, then at weeks 40, 92 and 120 in the OLE. In both RCTs, radiographs were assessed by two experienced readers using the SvdH method. They simultaneously scored all available radiographs/time-points per patient.

In the SvdH method, erosions are assigned scores per joint from 0 (no erosion) to a maximum of 5 (complete destruction of the joint) in the hands and a maximum of 10 in the feet. The maximum total erosion score in the hands is 160 , and in the feet it is 120 . JSN is scored from 0 (no JSN) to 4 (complete ankylosis or luxation), with a maximum total JSN of 120 in the hands and a maximum of 48 in the feet.

In this trial, 'JSN' has been documented as 'real JSN' or as SLUX separately: real JSN has been scored on a scale of 0-4. SLUX has been scored as 0 (no SLUX), 1 (subluxation) or 2 (luxation). This distinction allowed us to investigate all three components of the SvdH-score separately. Separate scores per reader were used for our analysis.

\section{Statistical analysis}

Statistical analyses were performed using IBM SPSS Statistics V.20 software. Generalised estimating equations (GEE) were used to investigate the relationship over time between E, real JSN, and SLUX, and physical function (HAQ), while adjusting for within-patient correlation. GEE is a technique that can be used for longitudinal data analysis, making use of data from all time points and adjusting for within-patient correlation, that is, correlation between time points within the same patient. ${ }^{13}$ GEE does not require a normal distribution of the dependent variable, which makes it attractive for analysing radiographic data. Covariance was modelled using an 'exchangeable' correlation structure, which assumes constant correlations between repeated measurements over time. 
The dependent (outcome) variable was the HAQ-score, either as a continuous score or as a dichotomous HAQ (with a cut-off level at 0.5 ), ${ }^{14}$ assessed at the same time points as the radiographs. Radiographic damage was modelled as E-score, 'real' JSN-score and SLUX-score, in three different ways: as dichotomous variable (presence vs absence of damage), as a countvariable (number of joints with damage), or as a continuous-variable (SvdH-score). Radiographic damage was assessed separately in four different joint groups: wrists, metacarpophalangeal joints (MCPs), proximal interphalangeal joints (PIPs), metatarsophalangeal joints (MTPs). Since SLUX is very rarely scored in the wrists and in the PIPs, we have excluded these joint groups when analysing SLUX.

The explanatory variables were entered in the models in the following order:

Step 1: E, 'real' JSN and SLUX in all joints were entered separately;

Step 2: All three types of damage in all joint groups were entered simultaneously in the model and backward selection was used to evaluate the independent contribution of all factors;

Step 3: Each type of damage was entered separately per joint group;

Step 4: E, 'real' JSN and SLUX per joint group were entered simultaneously, and backward selection was used to evaluate the independent contribution of all factors. All analyses were adjusted for Disease Activity Score 28 (DAS28) at baseline, age, gender and treatment group. Interactions for gender and treatment group were formally excluded before running the models.

The analyses were first performed in the RAPID 1 data set, and then repeated on the RAPID 2 data set. $p$ Values of $\leq 0.05$ were considered statistically significant.

\section{RESULTS}

A total of 847 patients from RAPID 1 and 567 patients from RAPID 2 were included in our study, respectively $86 \%$ and $92 \%$ of the originally randomised patients. The baseline characteristics of the patients from the two cohorts are presented in table 1 and show that both cohorts were generally similar. Both readers from each of the studies have found similar levels of radiographic damage but mean baseline radiographic damage was lower in RAPID 2 than in RAPID 1.

\section{RAPID 1 analysis}

In the separate models of E, 'real' JSN and SLUX scores in all joint groups (table 2), E and 'real' JSN were associated with HAQ-score (expressed as a continuous variable and as a dichotomous variable), regardless of the reader. The association between SLUX and HAQ-score was stronger, but this was only statistically significant for reader 2 .

Splitting up total E-scores into segmental E-scores (wrists, MCPs, PIPs, MTPs) yielded essentially similar associations (table 3), suggesting that either segmental E-scores are strongly correlated or that all separate segments correlate with HAQ-score. Similar results were found for 'real' JSN. Associations between segmental SLUX-scores and HAQ-score were numerically stronger, but not statistically significant (except for SLUX MCPs and HAQ-score by reader 2).

In order to further disentangle whether all segments contributed significantly to the association between erosions and HAQ-score, JSN and HAQ-score, and SLUX and HAQ-score, we performed a series of multivariable analyses (tables 2 and 3, lower part).

If E-score (all joints), JSN-score (all joints) and SLUX-score (all joints) were multivariably correlated to

Table 1 Baseline characteristics of RAPID 1 and RAPID 2 patients (all results are mean (SD) unless stated otherwise)

\begin{tabular}{|c|c|c|}
\hline & $\begin{array}{l}\text { RAPID } 1 \\
\mathrm{~N}=847\end{array}$ & $\begin{array}{l}\text { RAPID } 2 \\
\mathrm{~N}=567\end{array}$ \\
\hline Age (years) & $51.6(11.4)$ & $51.6(11.7)$ \\
\hline Sex (female)* & 701 (82.8) & $463(81.7)$ \\
\hline Rheumatoid factor positivity* & $695(82.1)$ & $422(74.4)$ \\
\hline DAS28 & $6.9(0.8)$ & $6.82(0.8)$ \\
\hline HAQ (0-3) & $1.7(0.6)$ & $1.6(0.6)$ \\
\hline $\mathrm{HAQ}(>0.5)^{*}$ & $805(95.0)$ & $537(94.7)$ \\
\hline Disease duration (years) & $6.2(4.3)$ & $6.2(4.1)$ \\
\hline \multicolumn{3}{|l|}{ Reader 1} \\
\hline Total E-score† & 18.5 (28.3), 0-195 & 16.3 (25.2), 0-189 \\
\hline Total real JSN-score† & 22.6 (29.2), 0-147 & 18.2 (23.7), 0-126 \\
\hline Total SLUX-score† & 1.1 (3.1), 0-26 & $1.0(2.6), 0-15$ \\
\hline \multicolumn{3}{|l|}{ Reader 2} \\
\hline Total E-score & 29.5 (35.9), 0-209 & 16.27 (24.5), 0-188 \\
\hline Total real JSN-score† & 32.9 (32.8), 0-165 & 14.76 (20.7), 0-128 \\
\hline Total SLUX-score $†$ & $1.1(2.7), 0-20$ & $0.88(2.5), 0-18$ \\
\hline $\begin{array}{l}\text { *n (\%). } \\
\text { †Mean (SD), minimum-maximur } \\
\text { DAS28, Disease Activity Score }\end{array}$ & sment Questionna & APID, Rheumatoid \\
\hline
\end{tabular}


Table 2 Relationship between radiographic damage in all joint groups (univariable models with separate predictors (step 1), and multivariable models (step 2)) and physical function (either by HAQ continuous or by HAQ dichotomous)

\begin{tabular}{|c|c|c|c|c|}
\hline & \multicolumn{2}{|l|}{ HAQ continuous } & \multicolumn{2}{|l|}{ HAQ dichotomous } \\
\hline & $\begin{array}{l}\text { Reader } 1 \\
\beta(95 \% \mathrm{Cl})\end{array}$ & $\begin{array}{l}\text { Reader } 2 \\
\beta(95 \% \mathrm{Cl})\end{array}$ & $\begin{array}{l}\text { Reader } 1 \\
\text { OR }(95 \% \mathrm{Cl})\end{array}$ & $\begin{array}{l}\text { Reader } 2 \\
\text { OR }(95 \% \mathrm{Cl})\end{array}$ \\
\hline \multicolumn{5}{|l|}{ Predictors, separate models $†$} \\
\hline Erosions all joint groups & $\begin{array}{l}0.002 \\
(0.001 \text { to } 0.003)^{\star *}\end{array}$ & $\begin{array}{l}0.002 \\
(0.001 \text { to } 0.003)^{\star * *}\end{array}$ & $\begin{array}{l}1.008 \\
(1.003 \text { to } 1.014)^{\star \star}\end{array}$ & $\begin{array}{l}1.007 \\
(1.003 \text { to } 1.012)^{\star *}\end{array}$ \\
\hline Real JSN all joint groups & $\begin{array}{l}0.002 \\
(0.001 \text { to } 0.003)^{\star \star \star}\end{array}$ & $\begin{array}{l}0.003 \\
(0.002 \text { to } 0.004)^{\star \star \star}\end{array}$ & $\begin{array}{l}1.010 \\
(1.004 \text { to } 1.016)^{\star \star \star}\end{array}$ & $\begin{array}{l}1.011 \\
(1.006 \text { to } 1.016)^{\star \star *}\end{array}$ \\
\hline SLUX all joint groups & $\begin{array}{l}0.002 \\
(-0.009 \text { to } 0.013)\end{array}$ & $\begin{array}{l}0.017 \\
(0.003 \text { to } 0.031)^{*}\end{array}$ & $\begin{array}{l}1.055 \\
(0.994 \text { to } 1.119)\end{array}$ & $\begin{array}{l}1.079 \\
(1.012 \text { to } 1.051)^{\star}\end{array}$ \\
\hline \multicolumn{5}{|c|}{ Predictors, combined models $\ddagger$} \\
\hline Erosions all joint groups & - & - & - & - \\
\hline Real JSN all joint groups & $\begin{array}{l}0.003 \\
(0.002 \text { to } 0.005)^{\star \star \star}\end{array}$ & $\begin{array}{l}0.003 \\
(0.002 \text { to } 0.004)^{* * *}\end{array}$ & $\begin{array}{l}1.010 \\
(1.004 \text { to } 1.016)^{\star * *}\end{array}$ & $\begin{array}{l}1.011 \\
(1.006 \text { to } 1.016)^{\star \star \star}\end{array}$ \\
\hline SLUX all joint groups & $\begin{array}{l}-0.017 \\
(-0.030 \text { to }-0.004)^{*}\end{array}$ & - & - & - \\
\hline $\begin{array}{l}\mathrm{p} \leq \mathrm{U} \text {; } \\
\text { tGEE, adjusted for age, genc } \\
\text { fGEE (backward selection), } \\
-, \text { variable not included in the }\end{array}$ & $\begin{array}{l}\text { siswe NS. } \\
\text { seline DAS28, treatmel } \\
\text { d for age, gender, base } \\
\text { nodel; DAS28, Disease }\end{array}$ & $\begin{array}{l}\text { S28, treatment gro } \\
\text { Score 28; GEE, } 9\end{array}$ & $\begin{array}{l}\text { ults are last step } \\
\text { estimating equat }\end{array}$ & $\begin{array}{l}\text { gression. } \\
A Q \text {, Health }\end{array}$ \\
\hline
\end{tabular}

HAQ-score, 'real' JSN seemed to be dominant in explaining the association between damage (E, JSN, SLUX) and physical function (HAQ-score), and the effects of E and SLUX were entirely captured by JSN (table 2).

Subsequently, all segmental joint scores (E-scores, JSN-scores and SLUX-scores) were tested in one model against HAQ-score (table 3), and it turned out that the association between damage scores and HAQ-score was largely determined by erosions in the wrists and 'real JSN' in the MCPs.

Although there are some differences between the scores of the two readers, they are small and, in general, the results of our analysis are consistent for both readers, regardless of the type of outcome variable used (HAQ continuous or dichotomous).

Interactions between damage variables and gender or treatment were tested and not considered relevant.

\section{RAPID 2 analysis}

All separate models were also tested in the RAPID 2 trial. While the values obtained for the parameter estimates and the CIs were largely similar (though with somewhat lower parameter estimates) to those obtained in RAPID 1 (see online supplementary table S1), the results did not reach statistical significance.

\section{DISCUSSION}

The present study, performed in patients with RA from two RCTs on CZP, analysed the relationship between present radiographic damage and HAQ-score in RA. Radiographic damage in RA, as quantified by the SvdH, is a combination (sum-score) of erosions (operationalised as the E-score) and JSN (operationalised as the JSN-score). We have factored in a third type of damage-SLUX-that is visible and quantifiable on radiographs but is usually part of the JSN-score and cannot be separated from that. In this particular analysis, we were able to unravel 'real JSN' from '(sub)luxation', so that we could investigate if SLUX had an independent contribution to explaining physical function.

One of the main conclusions of this analysis is that we could not find such an independent contribution of SLUX to explain the variation in HAQ-score. In accordance with other studies, we found 'real JSN' to be most contributory to explaining the HAQ-score. ${ }^{1}$ That does not mean that SLUX (or erosion) is not important; in fact, there was a numerical association between subluxation-score and HAQ-score that was not statistically significant. It only indicates that the contribution of erosions and SLUX is appropriately captured by JSN. In other words: erosions and SLUX in this cohort rarely occur as the only phenomena, but, usually-if not always -in conjunction with JSN. An alternative explanation could be that erosions and SLUX are rare phenomena in comparison with 'real' JSN. That is definitely not true for erosions, which occur as often as 'real' JSN, but likely true for SLUX that were indeed rare in these trials. Since SLUX is a known late consequence of long-term RA, and the effects of SLUX are captured by JSN, the inclusion of SLUX in the scoring method for radiographic damage does not seem to be very relevant. However, there is also no indication that SLUX jeopardises the performance of the modified Sharp score, and it does not make sense to remove SLUX from the current score.

Our present study partially confirms the results of a previous study by Aletaha et al, ${ }^{1}$ suggesting that JSN is 
Table 3 Relationship between radiographic damage in separate joint groups (univariable models with separate predictors (step 3), and multivariable models with combined predictors (step 4)) and physical function (either by HAQ continuous or by $\mathrm{HAQ}$ dichotomous)

\begin{tabular}{|c|c|c|c|c|}
\hline & \multicolumn{2}{|l|}{ HAQ continuous } & \multicolumn{2}{|l|}{ HAQ dichotomous } \\
\hline & $\begin{array}{l}\text { Reader } 1 \\
\beta(95 \% \mathrm{Cl})\end{array}$ & $\begin{array}{l}\text { Reader } 2 \\
\beta(95 \% \mathrm{Cl})\end{array}$ & $\begin{array}{l}\text { Reader } 1 \\
\text { OR }(95 \% \mathrm{CI})\end{array}$ & $\begin{array}{l}\text { Reader } 2 \\
\text { OR }(95 \% \mathrm{Cl})\end{array}$ \\
\hline \multicolumn{5}{|c|}{ Predictors, separate models $†$} \\
\hline Erosions wrists & $\begin{array}{l}0.007 \\
(0.004 \text { to } 0.011)^{\star \star \star}\end{array}$ & $\begin{array}{l}0.006 \\
(0.004 \text { to } 0.009)^{\star \star \star}\end{array}$ & $\begin{array}{l}1.034 \\
(1.015 \text { to } 1.054)^{\star \star \star}\end{array}$ & $\begin{array}{l}1.023 \\
(1.011 \text { to } 1.035)^{\star \star \star}\end{array}$ \\
\hline Erosions MCPs & $\begin{array}{l}0.005 \\
(0.000 \text { to } 0.010)^{*}\end{array}$ & $\begin{array}{l}0.006 \\
(0.001 \text { to } 0.010)^{*}\end{array}$ & $\begin{array}{l}1.013 \\
(0.993 \text { to } 1.033)\end{array}$ & $\begin{array}{l}1.014 \\
(0.997 \text { to } 1.032)\end{array}$ \\
\hline Erosions PIPs & $\begin{array}{l}0.012 \\
(0.002 \text { to } 0.022)^{*}\end{array}$ & $\begin{array}{l}0.012 \\
(0.005 \text { to } 0.019)^{\star \star *}\end{array}$ & $\begin{array}{l}1.040 \\
(0.994 \text { to } 1.089)\end{array}$ & $\begin{array}{l}1.038 \\
(1.009 \text { to } 1.068)^{\star}\end{array}$ \\
\hline Erosions MTPs & $\begin{array}{l}0.002 \\
(-0.001 \text { to } 0.004)\end{array}$ & $\begin{array}{l}0.003 \\
(0.001 \text { to } 0.005)^{\star \star}\end{array}$ & $\begin{array}{l}1.011 \\
(1.000 \text { to } 1.022)^{*}\end{array}$ & $\begin{array}{l}1.012 \\
(1.002 \text { to } 1.022)^{\star}\end{array}$ \\
\hline Real JSN wrists & $\begin{array}{l}0.005 \\
(0.002 \text { to } 0.008)^{\star \star \star}\end{array}$ & $\begin{array}{l}0.007 \\
(0.004 \text { to } 0.009)^{\star \star \star}\end{array}$ & $\begin{array}{l}1.024 \\
(1.010 \text { to } 1.039)^{\star \star \star}\end{array}$ & $\begin{array}{l}1.027 \\
(1.014 \text { to } 1.041)^{\star \star}\end{array}$ \\
\hline Real JSN MCPs & $\begin{array}{l}0.007 \\
(0.003 \text { to } 0.011)^{\star *}\end{array}$ & $\begin{array}{l}0.008 \\
(0.004 \text { to } 0.012)^{\star * *}\end{array}$ & $\begin{array}{l}1.025 \\
(1.006 \text { to } 1.044)^{\star *}\end{array}$ & $\begin{array}{l}1.031 \\
(1.012 \text { to } 1.049)^{\star * \star}\end{array}$ \\
\hline Real JSN PIPs & $\begin{array}{l}0.011 \\
(0.003 \text { to } 0.019)^{\star *}\end{array}$ & $\begin{array}{l}0.014 \\
(0.008 \text { to } 0.021)^{\star * *}\end{array}$ & $\begin{array}{l}1.044 \\
(1.007 \text { to } 1.082)^{\star}\end{array}$ & $\begin{array}{l}1.044 \\
(1.016 \text { to } 1.071)^{\star \star}\end{array}$ \\
\hline Real JSN MTPs & $\begin{array}{l}0.003 \\
(0.000 \text { to } 0.006)^{\star}\end{array}$ & $\begin{array}{l}0.004 \\
(0.001 \text { to } 0.007)^{\star \star}\end{array}$ & $\begin{array}{l}1.016 \\
(1.003 \text { to } 1.029)^{\star}\end{array}$ & $\begin{array}{l}1.019 \\
(1.007 \text { to } 1.031)^{\star \star \star}\end{array}$ \\
\hline SLUX MCPS & $\begin{array}{l}0.013 \\
(-0.013 \text { to } 0.04)\end{array}$ & $\begin{array}{l}0.052 \\
(0.023 \text { to } 0.082)^{\star \star \star}\end{array}$ & $\begin{array}{l}1.124 \\
(0.939 \text { to } 1.345)\end{array}$ & $\begin{array}{l}1.305 \\
(1.055 \text { to } 1.613)^{\star}\end{array}$ \\
\hline SLUX MTPS & $\begin{array}{l}0.000 \\
(-0.013 \text { to } 0.013)\end{array}$ & $\begin{array}{l}0.015 \\
(-0.001 \text { to } 0.031)\end{array}$ & $\begin{array}{l}1.056 \\
(0.986 \text { to } 1.132)\end{array}$ & $\begin{array}{l}1.088 \\
(1.008 \text { to } 1.175)^{\star}\end{array}$ \\
\hline \multicolumn{5}{|c|}{ Predictors, combined modelsł } \\
\hline Erosions wrists & $\begin{array}{l}0.007 \\
(0.004 \text { to } 0.011)^{\star * *}\end{array}$ & $\begin{array}{l}0.006 \\
(0.003 \text { to } 0.009)^{\star \star *}\end{array}$ & $\begin{array}{l}1.035 \\
(1.013 \text { to } 1.057)^{\star \star}\end{array}$ & $\begin{array}{l}1.023 \\
(1.009 \text { to } 1.038)^{\star \star \star}\end{array}$ \\
\hline Erosions MCPs & - & $\begin{array}{l}-0.010 \\
(-0.018 \text { to }-0.002)^{\star}\end{array}$ & $\begin{array}{l}0.960 \\
(0.932 \text { to } 0.989)^{\star \star}\end{array}$ & $\begin{array}{l}0.948 \\
(0.920 \text { to } 0.977)^{\star \star \star}\end{array}$ \\
\hline Erosions PIPs & - & - & - & - \\
\hline Erosions MTPs & - & - & - & - \\
\hline Real JSN wrists & - & - & - & - \\
\hline Real JSN MCPS & - & $\begin{array}{l}0.012 \\
(0.005 \text { to } 0.020)^{\star *}\end{array}$ & $\begin{array}{l}1.041 \\
(1.012 \text { to } 1.070)^{\star *}\end{array}$ & $\begin{array}{l}1.059 \\
(1.027 \text { to } 1.092)^{\star \star *}\end{array}$ \\
\hline Real JSN PIPs & - & - & - & - \\
\hline Real JSN MTPS & - & - & - & - \\
\hline SLUX MCPS & - & - & - & - \\
\hline SLUX MTPS & - & - & - & - \\
\hline \multicolumn{5}{|c|}{$\begin{array}{l}{ }^{*} \mathrm{p} \leq 0.05 ;{ }^{* *} \mathrm{p} \leq 0.01 ;{ }^{* * *} \mathrm{p} \leq 0.001 \text {; otherwise NS. } \\
\text { †GEE, adjusted for age, gender, baseline DAS28, treatment group. } \\
\text { †GEE (backward selection), adjusted for age, gender, baseline DAS28, treatment group; all results are last step of the regression. } \\
\text {-, variable not included in the final model; DAS28, Disease Activity Score 28; GEE, generalised estimating equations; HAQ, Health } \\
\text { Assessment Questionnaire; JSN, joint space narrowing; MCPs, metacarpophalangeal joints; MTP, metatarsophalangeal joints; NS, not } \\
\text { significant; PIPS, proximal interphalangeal joints; SLUX, (sub)luxation. }\end{array}$} \\
\hline
\end{tabular}

more clearly associated with irreversible physical disability than with erosions. This study did not further distinguish soft tissue damage (SLUX) from cartilage loss ('real' JSN). A recent study of ours ${ }^{8}$ performed in an observational cohort followed up for 10 years investigated the contribution of the three types of radiographic joint damage on several aspects of functional outcome (HAQ-score, grip strength, dexterity-score) in patients with RA. Patients in that cohort did not receive biological therapy, and had a long follow-up period (10 years), with consequently more radiographic progression, including more SLUX, than did the RAPID trials. But even in that study, an independent contribution of SLUX on any of the studied outcomes could not be proven.

When assessing the association between different types of radiographic damage on HAQ per joint group, our results are in line with those of Koevoets et al. ${ }^{15}$ They have shown that erosions occurring in the wrist were the main contributor to disability. The wrist has also been found to be the most important site for explaining impaired grip strength in our previous study. ${ }^{8}$ A possible explanation is that the wrist is actively involved in many of the daily activities of the HAQ questionnaire. 
The strength of our study lies in the large number of patients, the completeness of the data and also in the statistical methods used. GEE is a multivariable analysis technique that allows investigating the association of radiographic damage in relationship to function while covering multiple time points, thus not 'spoiling' informative data. 815

We are aware of several limitations of this study. One limitation is the high number of statistical tests performed and the sensitivity of methods such as GEE that make use of all data available, which may occasionally lead to spurious associations (eg, negative correlations where positive correlations were expected). Reassuringly, though, our results were in line with data from previous studies.

It is also important to point out that readers should not pay too much attention to the magnitude of the regression coefficients, as these reflect rather artificial associations of decomposed structural measures with functional measures, but rather to the sign (positive vs negative) and the level of statistical significance. These latter confirm the association and the direction of the association.

A surprising finding was the fact that the RAPID 2 trial did not yield statistically significant results, although all associations were in the same direction. Some characteristics of the RAPID 2 trial (fewer patients than in RAPID 1, lower radiographic damage at baseline and subsequently lower radiographic progression) may have had an influence on the results. However, this inconsistency underlines the challenge faced when investigating the relationship between radiographic damage and functional disability, and we are not able to fully explain it.

In addition, there may be other factors worth considering when analysing the relationship between radiographic damage and physical function. One could be the way physical function is measured. Although the HAQ is the most widely used functional outcome measurement, it has several issues, such as a particular focus on function of the hands; ${ }^{16}$ however, larger joints, such as joints of the knee, may impact physical function to a greater extent than the joints of the hands, ${ }^{17}$ which would be underestimated by the HAQ-score. If so, this implies that the association between radiographic damage and physical function is even stronger than our results show.

There are also some methodological issues of using HAQ for instance: (1) it is a generic rather than a disease-specific instrument; (2) it is not sensitive to change at both ends of the spectrum (floor and ceiling effects); (3) HAQ raw scores are ordinal scores and therefore not strictly suitable for parametric statistical analysis. ${ }^{18}{ }^{19}$ Although the HAQ is usually employed satisfactorily as a continuous measure in clinical trials, it is questionable to what extent the subtle relationships between radiographic scores and HAQ-scores are hampered by these methodological issues. ${ }^{9}$ If these limitations are overcome and a better way of assessing the outcome of functional disability is developed, the relationship between radiographic damage and functional disability may become less challenging to address, and may become clearer. Studying other functional outcome measures (not available for the present study), such as Arthritis Impact Measurement Scales (AIMS/ AIMS2), ${ }^{20}{ }^{21}$ or performance-based methods, such as grip strength, might be a useful addition when addressing this complex relationship between radiographic damage and physical functioning.

Another factor to consider in the relationship between radiographic damage and physical function is the means of quantification of radiographic damage. We have 'decomposed' the SvdH-score into three separate parts, which were subsequently analysed in four different joint groups, using the separate scores of the two readers; the objective was to obtain better insight into the details of a very complex relationship. In addition, this was performed in an attempt to reflect damage of different anatomic structures and to relate it with function. Nevertheless, a very clear distinction of structures involved is very difficult or even impossible as, for example, SLUX can reflect damage in the soft tissue, but is frequently also associated with bone or cartilage damage. However, while the results of our analysis may suggest that an important part of variation in HAQ-score could be explained solely by a few components of the SvdH-score, in fact, there are still many reasons to use a total composite score. The patients included in this study represent a (highly) selected population that is eligible for RCTs: they have high disease activity at baseline and radiographic damage already present at baseline, and thus a relatively high likelihood of radiographic progression. ${ }^{22}$ In these patients, more joints are more likely to be affected by both erosions and JSN, ${ }^{23}$ which are not independent (the existence of damage in 1 joint makes it more likely to have damage in other joints as well), so there is likely some redundancy with regard to radiological information conveyed by components. This redundancy can also explain why some types of lesions (eg, 'real' JSN) are independently associated with functional disability while others are not. These results in fact confirm what has been previously shown regarding radiographic damage: that a composite score (such as the SvdH-score) is appropriate for radiographic scoring. ${ }^{23-25}$

In conclusion, this study gives better insight into the complex relationship between radiographic damage and disability. Erosions and JSN are both important elements of damage. The separate contribution of SLUX to explaining physical function seems trivial.

Author affiliations

${ }^{1}$ Department of Rheumatology, Leiden University Medical Center, Leiden, The Netherlands

${ }^{2}$ Internal Medicine and Rheumatology Department, Cantacuzino Hospital, Bucharest, Romania

${ }^{3}$ Amsterdam Rheumatology \& Clinical Immunology Center, Amsterdam, The Netherlands

${ }^{4}$ Atrium Medical Center Heerlen, Heerlen, The Netherlands 
Acknowledgements The authors thank UCB for kindly providing the data from RAPID 1 and RAPID 2 randomised clinical trials.

Funding AMG was supported by an EULAR scientific training bursary for 6 months and by an unrestricted scientific grant from UCB.

Competing interests DvdH is director of Imaging Rheumatology BV, The Netherlands. $\mathrm{RL}$ is director of Rheumatology Consultancy BV, The Netherlands.

Patient consent Obtained.

Ethics approval The RAPID 1 and RAPID 2 trials were approved by an institutional review committee at each participating centre.

Provenance and peer review Not commissioned; externally peer reviewed.

Data sharing statement No additional data are available.

Open Access This is an Open Access article distributed in accordance with the Creative Commons Attribution Non Commercial (CC BY-NC 4.0) license, which permits others to distribute, remix, adapt, build upon this work noncommercially, and license their derivative works on different terms, provided the original work is properly cited and the use is non-commercial. See: http:// creativecommons.org/licenses/by-nc/4.0/

\section{REFERENCES}

1. Aletaha D, Funovits J, Smolen JS. Physical disability in rheumatoid arthritis is associated with cartilage damage rather than bone destruction. Ann Rheum Dis 2011;70:733-9.

2. Aletaha D, Smolen J, Ward MM. Measuring function in rheumatoid arthritis: identifying reversible and irreversible components. Arthritis Rheum 2006;54:2784-92.

3. Breedveld FC, Han C, Bala M, et al. Association between baseline radiographic damage and improvement in physical function after treatment of patients with rheumatoid arthritis. Ann Rheum Dis 2005;64:52-5.

4. Scott DL, Pugner K, Kaarela K, et al. The links between joint damage and disability in rheumatoid arthritis. Rheumatology (Oxford) 2000;39:122-32.

5. Smolen JS, van der Heijde DM, Aletaha D, et al. Progression of radiographic joint damage in rheumatoid arthritis: independence of erosions and joint space narrowing. Ann Rheum Dis 2009;68:1535-40.

6. van der Heijde D, Landewe R, van Vollenhoven R, et al. Level of radiographic damage and radiographic progression are determinants of physical function: a longitudinal analysis of the TEMPO trial. Ann Rheum Dis 2008;67:1267-70.

7. van der Heijde D. How to read radiographs according to the Sharp/ van der Heijde method. J Rheumatol 2000;27:261-3.

8. Navarro-Compan V, Landewe R, Provan SA, et al. Relationship between types of radiographic damage and disability in patients with rheumatoid arthritis in the EURIDISS cohort: a longitudinal study. Rheumatology (Oxford) 2015:54:83-90.

9. Landewe R, van der Heijde D. Joint space narrowing, cartilage and physical function: are we deceived by measurements and distributions? Ann Rheum Dis 2011;70:717-18.

10. Keystone E, Heijde DV, Mason D Jr, et al. Certolizumab pegol plus methotrexate is significantly more effective than placebo plus methotrexate in active rheumatoid arthritis: findings of a fifty-two-week, phase III, multicenter, randomized, double-blind, placebo-controlled, parallel-group study. Arthritis Rheum 2008;58:3319-29.

11. Smolen J, Landewe RB, Mease $\mathrm{P}$, et al. Efficacy and safety of certolizumab pegol plus methotrexate in active rheumatoid arthritis: the RAPID 2 study. A randomised controlled trial. Ann Rheum Dis 2009;68:797-804

12. Fries JF, Spitz P, Kraines RG, et al. Measurement of patient outcome in arthritis. Arthritis Rheum 1980;23:137-45.

13. WR TJ. Applied longitudinal data analysis for epidemiology A practical guide. Cambridge: Cambridge University Press, 2003.

14. Maska L, Anderson J, Michaud K. Measures of functional status and quality of life in rheumatoid arthritis: Health Assessment

Questionnaire Disability Index (HAQ), Modified Health Assessment Questionnaire (MHAQ), Multidimensional Health Assessment Questionnaire (MDHAQ), Health Assessment Questionnaire II (HAQ-II), Improved Health Assessment Questionnaire (Improved HAQ), and Rheumatoid Arthritis Quality of Life (RAQoL). Arthritis Care Res (Hoboken) 2011;63(Suppl 11):S4-13.

15. Koevoets R, Dirven L, Klarenbeek NB, et al. 'Insights in the relationship of joint space narrowing versus erosive joint damage and physical functioning of patients with RA'. Ann Rheum Dis 2013;72:870-4.

16. Bjork MA, Thyberg IS, Skogh $\mathrm{T}$, et al. Hand function and activity limitation according to health assessment questionnaire in patients with rheumatoid arthritis and healthy referents: 5-year followup of predictors of activity limitation (The Swedish TIRA Project). J Rheumatol 2007;34:296-302.

17. Smolen JS, van der Heijde DM, Keystone EC, et al. Association of joint space narrowing with impairment of physical function and work ability in patients with early rheumatoid arthritis: protection beyond disease control by adalimumab plus methotrexate. Ann Rheum Dis 2013;72:1156-62.

18. Bruce B, Fries JF. The Stanford Health Assessment Questionnaire: a review of its history, issues, progress, and documentation. J Rheumatol 2003;30:167-78.

19. Tennant A, Hillman M, Fear J, et al. Are we making the most of the Stanford Health Assessment Questionnaire? Br J Rheumatol 1996;35:574-8.

20. Meenan RF, Gertman PM, Mason JH. Measuring health status in arthritis. The Arthritis Impact Measurement Scales. Arthritis Rheum 1980;23:146-52.

21. Meenan RF, Mason JH, Anderson JJ, et al. AIMS2. The content and properties of a revised and expanded Arthritis Impact Measurement Scales Health Status Questionnaire. Arthritis Rheum 1992;35:1-10

22. Landewe R, Strand V, van der Heijde D. From inhibition of radiographic progression to maintaining structural integrity: a methodological framework for radiographic progression in rheumatoid arthritis and psoriatic arthritis clinical trials. Ann Rheum Dis 2013;72:1113-17.

23. Strand V, Kingsbury SR, Woodworth T, et al. OMERACT 10 Sharp Symposium: important findings in examination of imaging methods for measurement of joint damage in rheumatoid arthritis. J Rheumatol 2011;38:2009-13.

24. Strand V, Sharp JT. Radiographic data from recent randomized controlled trials in rheumatoid arthritis: what have we learned? Arthritis Rheum 2003;48:21-34.

25. Landewe RB, Strand V, Conaghan PG, et al. Damage and progression on radiographs in individual joints: data from pivotal randomized controlled trials. J Rheumatol 2011;38: 2018-22. 